\title{
Peningkatan Ekonomi Masyarakat Melalui Inovasi Produk Olahan Keripik Kulit Singkong
}

\section{Increasing The Economy District Through The Innovation of Processed Cassava Skin Chips Product}

\author{
Syipaatul Rohimah ${ }^{1}$ Tuti Kurnia ${ }^{2}$ \\ ${ }^{1}$ Program Studi Ekonomi Syariah, Fakultas Ekonomi Islam, Universitas Djuanda Bogor Jl. Tol Ciawi No. \\ 1, Kotak Pos 35 Ciawi, Bogor 16720, e-mail: Syipaatul10@gmail.com \\ 2 Program Studi Ekonomi Syariah, Fakultas Ekonomi Islam, Universitas Djuanda Bogor Jl. Tol Ciawi No. 1, \\ Kotak Pos 35 Ciawi, Bogor 16720, e-mail: putrikoe22@gmail.com
}

(Diterima: 25-06-2020 Ditelaah: 25-09-2020; Disetujui: 10-02-2021)

\begin{abstract}
Abstrak
Sumber Daya Alam yang dihasilkan Desa Padamulya sangat melimpah, akan tetapi sumber daya alam yang dimiliki Desa Padamulya belum sepenuhnya dimanfaatkan oleh masyarakatnya, sehingga perlu adanya bimbingan atau pendampingan kepada masyarakat untuk memanfaatkan potensi yang ada. Salah satunya dengan memanfaatkan produk olahan kulit singkong yang dibuat menjadi sebuah makanan dengan harga nilai jual tinggi. Metode yang dilakukan adalah dengan sosialisasi dan pembuatan inovasi produk olahan singkong. Dalam pengolahan produk olahan kulit singkong ini penulis membuat keripik kulit singkong yang merupakan makanan cemilan enak dan sehat. Setelah dilaksanakan program ini hasil yang didapatkan adalah pengembangan produk olahan kulit singkong lebih kreatif dan inovatif serta masyarakat sekitar lebih memahami cara memanfaatkan sebuah potensi yang ada di sekitar.
\end{abstract}

Kata kunci: Inovasi Produk, Kulit Singkong, Pengabdian Masyarakat

\section{Abstract}

The natural resources produced by Padamulya Village are very abundant, but the natural resources owned by Padamulya Village have not been fully utilized by the community, so there is a need for guidance or assistance to the community to exploit the existing potential. One of them is by utilizing processed cassava skin products which are made into a food with high selling price. The method used is the socialization and innovation of cassava processed products. In processing this cassava skin processed product, the writer makes cassava skin chips which is a delicious and healthy snack food. After implementing this program, the results obtained are the development of cassava skin processed products more creative and innovative as well as the surrounding community better understanding how to utilize a potential that is around.

Keywords: Cassava, Community Service, Product Innovation

\section{PENDAHULUAN}

Pengabdian mahasiswa kepada masyarakat dilaksanakan untuk memenuhi salah satu tri dharma perguruan tinggi, yakni pengabdian kepada masyarakat yang bersifat lintas disiplin dan sebagai komponen keilmuan, teknologi dan seni secara aplikatif guna membentuk kehidupan masyarakat, utamanya di pedesaan. Bentuk pengabdian tersebut dilaksanakan dengan cara menerapkan ilmu pengetahuan yang sudah diperoleh di perkuliahan kepada masyarakat. Ilmu pengetahuan yang diterapkan adalah ilmu pengetahuan yang diperlukan oleh masyarakat atau yang dapat menjadi solusi bagi 
permasalahan yang terjadi kehidupan masyarakat. Hal ini dilakukan sebagai wujud rasa kepedulian dan tanggung jawab mahasiswa untuk memajukan bangsa dan negara di masa depan. (Lubis, 2004).

Desa Padamulya terletak diwilayah Kecamatan Pasirkuda Kabupaten Cianjur yang merupakan hasil dari pemekaran Desa Girimukti Dusun Cimahpar dan Desa Girijaya Dusun Lingkungsari, Desa ini memiliki luas tanah 2.312.373 Ha. yang terbagi menjadi 8 RW dan 17 RT letak Desa Padamulya berbatasan dengan Desa Girimukti Kecamatan Pasirkuda sebelah utara, Desa Girijaya Kecamatan Pasirkuda sebelah selatan, Desa Padasuka Kecamatan Cibinong sebelah timur, Desa Pusakajaya Kecamatan Pasirkuda dan Desa Kalibaru Kecamatan Pasirkuda sebelah barat. Jumlah penduduk Desa Padamulya bulan Agustus 2019 sebesar 3.410 jiwa yang terdiri dari 1.716 laki-laki, 1.694 perempuan yang mana mayoritas penduduk beragama Islam dari segi mata pencaharian yang ditekuni penduduk Desa Padamulya adalah seorang buruh tani hal ini disebabkan karena letak Desa Padamulya yang berbatasan dengan pegunungan sehingga memudahkan masyarakat untuk bercocok tanam. Adapun jumlah penduduk Desa Padamulya berdasarkan mata pencaharian adalah sebagai berikut:

Tabel 1. Mata Pencaharian Penduduk

\begin{tabular}{ccc}
\hline No. & Mata Pencaharian & Jumlah \\
\hline 1. & Petani & 340 orang \\
2. & Buruh tani & 699 orang \\
3. & Buruh & - \\
4. & Pengrajin & 163 orang \\
5. & PNS & 7 orang \\
6. & Pedagang & 213 orang \\
7. & Petani & 7 orang \\
\hline
\end{tabular}

Sumber: Profil Desa Padamulya

Sumber Daya Alam yang dihasilkan Desa Padamulya sangat melimpah, akan tetapi sumber daya alam yang dimiliki Desa Padamulya belum sepenuhnya dimanfaatkan oleh masyarakatnya, sehingga perlu adanya bimbingan atau pendampingan kepada masyarakat untuk memanfaatkan potensi yang ada. Salah satunya dengan memanfaatkan produk olahan kult singkong yang dibuat menjadi sebuah makanan dengan harga nilai jual tinggi. Pemilihan program pemanfaatan olahan kulit singkong ini dilakukan untuk mengurangi limbah kulit singkong serta limbah kulit singkong bisa memiliki nilai ekonomi.

Tumbuhnya industri kreatif di Indonesia disebabkan adanya krisis global yang berkepanjangan sehingga memunculkan semangat yang lebih dalam menciptakan, mengkreasikan, dan menginovasikan sesuatu dalam menciptakan ide-ide dan karyakarya yang baru. Arief Johari menyatakan bahwa pertumbuhan industri kreatif yang baik di Indonesia belum mampu memberikan pengaruh yang positif dan signifikan bagi Indonesia salah satu penyebabnya adalah "Manajemen Problem" yaitu suatu pemikiran 
yang menyebabkan adanya pemikiran bahwa sebuah produk yang dihasilkan hanya untuk konsumsi di dalam negeri sehingga hal inilah menyebabkan bahwa Indonesia termasuk pada kategorisasi sebagai negara konsumtif yang potensial secara internasiona. Berdasarkan uraian di atas maka perumusan masalah adalah ekonomi kreatif sebagai suatu solusi mensejahterakan masyarakat dalam meningkatkan tingkat perekonomian.

Dalam hal ini sebuah inovasi sangat diperlukan untuk bisa menciptakan ekonomi kreatif yang di inginkan. Adapun yang dimaksud dengan inovasi adalah sebuah gagasan, produk atau proses yang memiliki potensi untuk digunkan sebagai pemacu daya saing sebuah bangsa, wilayah, industri, organisasi, individu atau gabungan dari kategorikategori ini. Dengan memanfaatkan bahan bekas yang sudah tidak terpakai lalu di inovasikan menjadi sebuah produk yang layak dipasarkan dan layak untuk dihargai.

Kulit singkong (Manihot esculenta L. Skin) yang sering dianggap sebagai limbah dari tanaman singkong yang memiliki karbohidrat tinggi yang dapat digunakan sebagai sumber bagi ternak. Persentase jumlah limbah bagian luar sebesar 0,5-2\% dari berat total singkong segar dan limbah kulit bagian dalam sebesar 8-15\%. Limbah dari singkong ini mengandung beberapa komposisi 74,73\% nutrisi, 17,45\% bahan kering, $15,20 \%$ serat kasar, 0,63\% Ca, 0,22\% P (Sudaryanto, 1998).

Masyarakat pasti sudah tidak asing lagi dengan limbah singkong, salah satunya kulit singkong. Banyak masyarakat yang menjadikan sisa ketela menjadi ampas untuk pakan ternak, dijemur untuk dijadikan tepung ketela, dan juga diolah menjadi bahan makanan. Karena singkong merupakan makanan pokok kedua setelah beras maka limbahnya sudah pasti banyak. Kini masyarakat sudah bisa mengolah limbah kulit singkong sehingga limbah itu tidak terbengkalai namun alangkah baiknya apabila ide ide kreatif pengolahan limbah itu terus diciptakan seiring dengan majunya ilmu pengetahuan tentang kuliner di seluruh dunia, seperti mengolah kulitnya menjadi keripik.

\section{METODE PELAKSANAAN}

Metode pelaksanaan yang dilakukan penulis berupa partisipasi masyarakat aktif yakni dengan adanya pendampingan, pelatihan serta ceramah. Penulis dalam hal ini melakukan pendampingan ekonomi masyarakat dengan cara membentuk kelompok usaha yang akan mengembangkan potensi sumber daya alam yang ada disekitar wilayah desa Padamulya dengan membuat sebuah inovasi produk olahan kulit singkong.

Lokasi dan Waktu Penelitian

Adapun lokasi yang dijadikan tempat pelaksanaannya adalah Desa Padamulya, Kecamatan Pasirkuda, Kabupaten Cianjur, Provinsi Jawa Barat. Alasan dipilih Desa Padamulya sebagai karena kategori desa tersebut merupakan desa tertinggal, sehingga memerlukan banyak bantuan untuk mengembangkannya, terutama bantuan Sumber Daya Manusia (SDM) untuk mengembangkan potensi-potensi desa tersebut. 
Penyusunan Kegiatan Program

Kajian teori tersebut untuk mendukung penyusunan program kerja di bidang ekonomi untuk mengatasi permasalah-permasalah ekonomi di Kampung Sirnagalih Desa Padamulya. Berikut program kerja yang dilaksanakan terdapat pada Tabel 2.

Tabel 2. Program Kerja Yang Dilaksanakan

\begin{tabular}{l|l|l}
\hline NO & Program Kerja & Uraian Program \\
\hline 1 & $\begin{array}{l}\text { Pelatihan Pembuatan } \\
\text { Produk Olahan Keripik } \\
\text { Kulit Singkong. }\end{array}$ & $\begin{array}{l}\text { Pelatihan pembuatan inovasi produk olahan } \\
\text { kulit singkong dapat meningkatkan nilai jual } \\
\text { singkong tersebut, dimana hal ini lah yang } \\
\text { mampu membantu memanfaatkan potensi } \\
\end{array}$ \\
& $\begin{array}{l}\text { yang ada sekaligus meningkatkan } \\
\text { perekonomian }\end{array}$ \\
\hline
\end{tabular}

\section{HASIL \& PEMBAHASAN}

Produk yang dihasilkan dari kegiatan Program ini adalah pemanfaatan kulit singkong yang diolah dan diberi nama keripik kulit singkong. Pembuatan produk tersebut bertujuan untuk meningkatkan nilai ekonomi yang tinggi untuk masyarakat Desa Padamulya. Metode pelaksanaan yang dilakukan penulis berupa program Pendampingan Ekonomi Masyarakat dengan cara membentuk kelompok usaha yang akan mengembangkan potensi sumber daya alam yang ada disekitar wilayah desa Padamulya salah satunya adalah kulit singkong.

Program produk keripik kulit singkong yang memanfaatkan limbah kulit singkong yang melimpah dipedesaan sangat efektif dijadikan sebagai cemilan bahkan oleh-oleh khas daerah tersebut. Dengan adanya pelaksanaan kegiatan pengabdian kepada masyarakat ini bermunculan ide untuk mengembangkan usaha kecil menengah dengan memanfaatkan banyaknya limbah kulit singkong kemudian dinamakan keripik kulit singkong dengan pengemasan menarik sehingga dapat menarik perhatian konsumen dan dapat menaikan tingkat perekonomian masyarakat Kampung Mekarjaya.

Pembuatan inovasi produk olahan kulit singkong melalui pelatihan masyarakat Kampung Mekarajya Desa Padmulya dilaksanakan berdasarkan observasi bahwa masyarakat Mekarjaya RT 02 RW 08 ini khususnya untuk ibu-ibu sebanyak 80\% adalah buruh tani dan menanam umbi-umbian di ladangnya. Adapun perubahan pasca pelaksanaan yang diharapkan adalah sebagai berikut: 
Tabel 2. Perubahan Yang Diharapkan

\begin{tabular}{c|l|l|l}
\hline NO & Keterangan & $\begin{array}{l}\text { Pasca } \\
\text { Pelaksanaan }\end{array}$ & Pra Pelaksanaan \\
\hline 1 & $\begin{array}{l}\text { Keterampilan } \\
\text { dalam mengolah } \\
\text { kulit singkong } \\
\text { menjadi sebuah } \\
\text { produk }\end{array}$ & $\begin{array}{l}\text { Belum memiliki } \\
\text { keterampilan }\end{array}$ & $\begin{array}{l}\text { Memiliki keterampilan } \\
\text { pengolahan Kulit singkong } \\
\text { menjadi produk }\end{array}$ \\
\hline 2 & Kulit Singkong & $\begin{array}{l}\text { Limbah dan } \\
\text { diolah menjadi } \\
\text { pakan ternak. }\end{array}$ & $\begin{array}{l}\text { Kulit singkong diolah menjadi } \\
\text { produk makanan ringan dan } \\
\text { memiliki nilai jual lebih tinggi }\end{array}$ \\
\hline 3 & $\begin{array}{l}\text { Nilai jual kulit } \\
\text { singkong. }\end{array}$ & $\begin{array}{l}\text { Tidak memiliki } \\
\text { nilai jual karena } \\
\text { dianggap } \\
\text { sebagai limbah. }\end{array}$ & $\begin{array}{l}\text { Meningkat karena ada nilai } \\
\text { tambah dari produk hasil } \\
\text { olahan djenis produk olahan } \\
\text { baru) }\end{array}$ \\
\hline 4 & $\begin{array}{l}\text { Pemasaran kulit } \\
\text { singkong. }\end{array}$ & $\begin{array}{l}\text { Dibuang, } \\
\text { dijadikan pakan } \\
\text { ternak karena } \\
\text { merupakan } \\
\text { limbah. }\end{array}$ & $\begin{array}{l}\text { Dipasarkan lebih luas karena } \\
\text { memiliki nilai ekonomis yang } \\
\text { tinggi, dapat didistribusikan ke } \\
\text { pasar dan supermarket }\end{array}$ \\
\hline
\end{tabular}

Pelaksanaan Program Pendampingan dan Pembuatan Produk Olahan Singkong

Berikut tahap pelaksanaan program pendampingan dan pembuatan produk olahan singkong.

Gambar 1. Tahap Pelaksanaan Penelitian

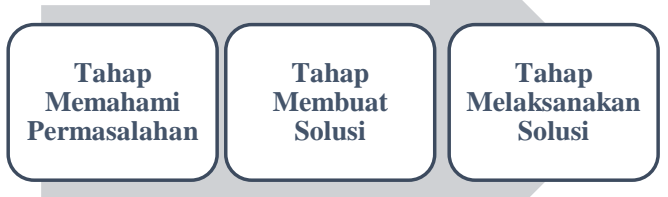

1) Tahap Memahami Permasalahan

Dalam tahap ini penulis memahami permasalahan dengan melakukan survei kepada masyarakat sekitar Kp. Mekarjaya Desa Padamulya dalam rangka melakukan identifikasi masalah yang ada. Sehingga penulis dapat merencanakan solusi untuk mengatasi masalah tersebut. Setelah melakukan identifikasi ditemukan bahwa permasalahan yang ada di Desa Padamulya adalah kurangnya pemanfaatan potensi sumber daya alam sehingga diperlukan pendampingan untuk meningkatkan potensi tersebut. 


\section{2) Tahap Membuat Solusi}

Dalam tahap membuat solusi terbagi menjadi beberapa tahap di antaranya:

a. Survei Potensi Sumber Daya Alam (SDA)

Survei lokasi dilakukan di wilayah Kp. Mekarjaya RT 02 RW 08 Desa Padamulya. Pelaksanaan survei dilakukan dengan cara melihat potensi limbah kulit singkong yang ada dikampung Mekarjaya, kemudian mencari tahu kebiasaan masyarakat dalam memanfaatkan limbah kulit singkong tersebut. Selain itu penulis juga melakukan survei dengan bertanya kepada masyarakat yang mempunyai limbah kulit singkong dirumahnya, kebanyakan masyarakat Mekarjaya membuang atau dijadikan pakan ternak terhadap limbah kulit singkong.

Hasil dari survei yang sudah dilakukan ialah, banyaknya limbah kulit singkong yang ada dikampung Mekarjaya yang hanya dibuang atau dijadikan pakan ternak. Sehingga munculah ide pembuatan keripik kulit singkong dengan tujuan untuk mengurangi limbah kulit singkong serta menaikkan harga jual kulit singkong tersebut melalui inovasi produk.

b. Pengembangan Inovasi Produk

Berdasarkan hasil survei yang dilakukan oleh tim pelaksana, banyak limbah kulit singkong yang ada diwilayah Padamulya tersebut. Untuk meminimalisir terjadinya kegagalan dalam pembuatan produk maka penulis melakukan percobaan dan pengembangan produk kulit singkong singkong tersebut. Percobaan pembuatan keripik kulit singkong ini dilakukan dua kali hingga menemukan hasil yang sempurna dan sesuai dengan apa yang diinginkan.

c. Membuat Desain Logo dan Kemasan

Ketika percobaan pembuatan produk berhasil, langkah selanjutnya adalah membuat desain logo dan kemasan yang dilakukan oleh penulis. Pembuatan desain kemasan dibuat dengan semenarik mungkin agar menarik perhatian konsumen. Dalam pemasaran produk, pembuatan nama yang menarik sangat penting untuk produk yang akan disebarluaskan di jangkauan kecil, menengah dan besar. Langkah pembuatan desain produk meliputi:

a. Penulis menggunakan aplikasi canva untuk membuat desain logo produk

b. Mencari gambar kulit singkong yang menarik dengan cara browsing.

c. Menentukan format penulisan, font, size dan warna.

d. Mencantumkan logo kelompok dan logo fakultas.

d. Pembelian Bahan Kebutuhan Produk

Penulis menyediakan kemasan produk yang sudah dibuat kemudian menyiapkan bahan-bahan untuk pembuatan keripik kulit singkong. Bahan-bahannya antara lain kulit singkong, bawang merah, bawang putih, merica, ketumbar, garam, penyedap rasa, air, dan minyak goreng.

e. Memberikan Informasi Kepada Masyarakat

Setelah melakukan survei lokasi, percobaan atau pengembangan produk dan membuat desain kemasan, penulis melakukan koordinasi dengan tokoh masyarakat setempat bahwa ada produk inovasi baru yang akan di sosialisasikan untuk masyarakat 
banyak. Pengumuman kepada masyarakat dilakukan sehari sebelum pelaksanaan demo pembuatan produk setelah melakukan perizinan.

3) Tahap Melaksanakan Solusi

Dalam melaksanakan solusi dilakukan dengan Pelatihan produk pembuaatan churros dingkong dilaksanakan pada tanggal 28 Agustus 2019 dan 29 Agustus 2019. Pelatihan produksi produk ini dihadiri oleh ibu-ibu sekitaran Kp. Sirnagalih. Sebelum produksi produk churros dilaksanakan, penulis menyampaikan terlebih dahulu kepada ibu-ibu akan dibuat seperti apa singkong tersebut.

Produksi pembuatan keripik kulit singkong dilakukan dengan beberapa tahap seperti proses rebusan guna menghilangkan rasa pahit pada kulit singkong, proses pencucian, proses pemotongan, proses penggorengan, proses pengolahan, proses pengemasan.

a. Tahap pertama, proses pembersihan kulit singkong dan pemotongan kulit singkong.

b. Tahap kedua, proses perebusan kulit singkong dengan air yang telah diberikan rempah-rempah sampai kulit singkong menjadi lunak.

c. Tahap ketiga, perendam kulit singkong selama dua hari dengan air yang selalu diganti setiap hari cara ini digunakan untuk menghilangkan rasa pahit dari kulit singkong.

d. Tahap keempat, yaitu proses penjemuran kulit singkong sampai kering

e. Tahap kelima, proses pengorengan kulit singkong.

f. Tahap keenam, proses pengemasan dilakukan setelah kulit singkong ditiriskan. Lalu masukan kedalam kemasan, lalu kemasan diberi sticker Berikut proses pengolahan singkong menjadi Churros Singkong:

a. Bahan-bahan:

1. kulit singkong $500 \mathrm{gr}$

2. garam $3 / 4$ sendok teh

3. $800 \mathrm{ml}$ air bersih

4. minyak goreng 500 gr

5. ketumbar Bubuk 1/2 sendok teh

6. bawang putih yang dihaluskan 5 siung

7. bawang merah yang dihaluskan 6 siung

8. Merica bubuk $1 / 2$ sendok teh

9. Penyedap rasa $1 / 2$ sendok teh

b. Cara pembuatan

a. Bersihkan kulit singkong dengan cara mengupas kulit tipis yang berwarna kecoklatan

b. Setelah itu kulit singkong dicuci dengan air sampai bersih

c. Rebus kulit singkong yang sudah bersih.

d. Lalu campurkan kulit singkong dengan ketumbar, bawang putih, gula merah dan garam halus sambil diaduk rata.

e. Angkat rebusan kulit singkong lalu lakukan perendaman selama 2-3 Hari. 
f. Jemur kulit singkong yang sudah dibumbui sampai benar-benar kering lalu diangkat

g. Goreng kulit singkong yang sudah kering dalam minyak panas sampai matang, angkat tiriskanTabel, grafik, atau gambar tidak boleh terlalu panjang, terlalu besar, atau terlalu banyak.

\section{KESIMPULAN}

Perekonomian masyarakat Desa Padamulya masih perlu untuk ditingkatkan. Walaupun perekonomian masyarakat Desa Padamulya masih dapat dikatakan standar, tetapi tingkat perekonomian Desa Padamulya tersebut dapat ditingkatkan melalui kegiatan ekonomi kreatif melalui inovasi produk. Melalui pengolahan limbah kulit singkong in menjadi kulit singkong diharapkan dapat meningkatkan pendapatan masyarakat serta berkurang limbah kulit singkong yang terdapat di Masyarakat. Hal ini dapat dimanfaatkan untuk menggali potensi masyarakat di bidang ekonomi dan dengan adanya kegiatan pelatihan inovasi produk olahan kulit singkong ini diharapkan dapat menjadi wadah bagi masyarakat untuk bisa memasarkannya sebagai sebuah oleh-oleh atau buah tangan khas Desa Padamulya.

Setelah mengikuti kegiatan pelatihan pembuatan inovasi produk olahan keripik kulit singkong para ibu rumah tangga diharapkan bisa mencari celah bisnis yang ada dan dapat mengembangkannya sendiri di rumah masing-masing serta meningkatkan pendapatan.

\section{DAFTAR PUSTAKA}

Aldy Purnomo, Rochmat. 2016. Ekonomi Kreatif Pilar Pembangunan Indonesia. Surakarta: Ziyad Visi Media.

Ariyani, (2017). Pemanfaatan Kulit Singkong Sebagai Bahan Baku Arang Aktif Dengan Variasi Konsentrasi Naoh Dan Suh

Hamali, Sambudi. (2016). Pengaruh Inovasi Terhadap Kinerja Bisnis Pada Industri Kecil Pakaian Jadi Kota Bandung.

Prasetyo, A. (2018). Potensi Peningkatan Produktivitas Kewirausahaan Berbasis Model Penguatan Teknopreneur pada Hasil Inovasi Kota Magelang. 